\title{
Cowpea mosaic virus from Vegetable Soybeans in Korea
}

\author{
Eui-Kyoo Cho* and Sin-Ho Lee \\ Major in Agricultural Biology, School of Bioresource Sciences, Andong National University, Andong, Kyungbuk 760-749, Korea \\ (Received on April 18, 2003; Accepted on May 23, 2003)
}

Ninety samples showing mosaic symptoms on soybean (Glycine max) cv. Sukryangputkong were collected from the Cheongsongkun area, Kyungbuk province in Korea. Initially, DAS-ELISA was conducted for detection of Soybean mosaic virus (SMV). Negative samples were chosen at random and mechanically inoculated on soybean cv. Buffalo, which reported not to produce mosaic symptoms when mechanically inoculated with SMV. An isolate of SMV, designated as B-1, from Buffalo showing mosaic and mottle symptoms was used for identification and biological characterization of the causal virus. The purified B-1 isolate had spherical particles of approximately $24 \mathrm{~nm}$. It positively reacted with the antiserum against Cowpea mosaic virus (CPMV) but not with Cucumber mosaic virus (CMV) and SMV antisera. CPMV was newly isolated from soybean and had been characterized by host range and by serological and electron microscopic methods. Results of this study suggest that CPMV is the possible cause of mosaic disease in vegetable soybean and that based on symptomatology, a difference between the typical mosaic and rugose symptoms caused by SMV and CPMV was observed. This is first report of CPMV from soybean in Korea.

Keywords : Cowpea mosaic virus, identification, serology, soybean

Several cases of severe mosaic disease infestation were observed on vegetable soybeans (Glycine max) in Cheongsong area, Kyungbuk province in Korea in 2000. Soybean mosaic virus (SMV) was considered as the possible cause of the mosaic disease. SMV has been known as a prevalent pathogen and is widely spread in Korea. Meanwhile, Cowpea mosaic virus (CPMV) was newly isolated from soybean and has been characterized by host range and by serological and electron microscopic methods. This paper reports that CPMV is the possible cause of mosaic disease in vegetable soybean and that based on symptomatology, a difference between the typical mosaic and rugose symptoms caused by SMV and CPMV was observed.

\footnotetext{
*Corresponding author.

Phone) +82-54-820-5507, FAX) +82-54-823-1628

E-mail) ekcho@ andong.ac.kr
}

\section{Materials and Methods}

Virus source and isolation of causal virus. Ninety samples showing mosaic symptoms on soybean cv. Sukryangputkong were collected from the Cheongsongkun area, Kyungbuk province in Korea. DAS-ELISA was conducted for detection of SMV, and negative samples were selected. Negative samples were chosen at random and mechanically inoculated on plants of soybean cv. Buffalo, previously reported not to produce mosaic symptoms when inoculated with SMV (Cho, 1978).

An isolate, designated B-1, from Buffalo showing mosaic and mottle symptoms were separated by successive single local lesion methods and used for identification and biological characterization of the causal virus (Fig. 1). The soybean cv. Buffalo was used to increase virus inoculum and to exclude possible mixed infec-
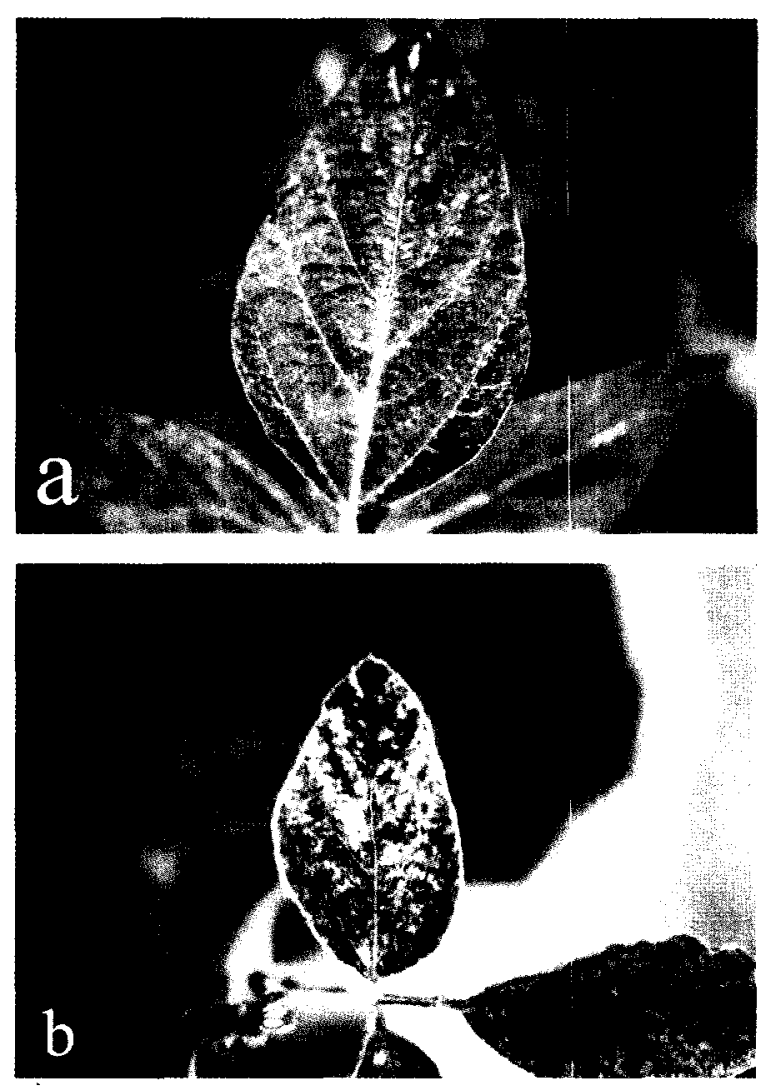

Fig. 1. Symptoms of Buffalo (soybean cultivar) inoculated with ELISA negative samples. a: mosaic symptom of noninoculated upper leaf, $\mathbf{b}$ : more severe symptom of new emerging leaves. 
Table 1. Reactions of isolate B-1, Cowpea mosaic virus, Soybean stunt virus and Alfalfa mosaic virus on different indicator plants

\begin{tabular}{|c|c|c|c|c|}
\hline \multirow{2}{*}{ Indicator plant } & \multicolumn{4}{|c|}{ Symptoms of B-1 isolate and other related legume virus ${ }^{\mathrm{a}}$} \\
\hline & $\mathrm{B}$-1 isolate & $\mathrm{CPMV}^{\mathrm{b}}$ & $\mathrm{SstV}^{\mathrm{c}}$ & $\mathrm{AMV}^{\mathrm{d}}$ \\
\hline Chenopodium amaranticolor & $\mathrm{L} / \mathrm{M}$ & $\mathrm{L} / \mathrm{M}$ & $\mathrm{L} /-$ & $\mathrm{L} / \mathrm{M}$ \\
\hline Gomphrena globosa & $l$ & $l$ & $-1-$ & $\mathrm{L} / \mathrm{YS}$ \\
\hline Cucumis sativus & $-1-$ & $-1-$ & $-/ \mathrm{M}$ & $\mathrm{L} / \mathrm{M}$ \\
\hline Datura stramonium & $-1-$ & $-1-$ & $-1-$ & $-1-$ \\
\hline Pisum sativum & $-/ \mathrm{M}, \mathrm{Mo}$ & $l / \mathrm{Mo}$ & $-1-$ & $\mathrm{L} / \mathrm{M}$ \\
\hline Phaseolus vulgaris cv. Top Crop & $-/ \mathrm{M}, \mathrm{Mo}$ & $-/ \mathrm{Mo}$ & $-1-$ & $\mathrm{L} /-$ \\
\hline Phaseolus vulgaris cv. Scotia & $-/ \mathrm{M}, \mathrm{Mo}$ & $\mathrm{L} / \mathrm{Mo}$ & $-1-$ & $\mathrm{L} /-$ \\
\hline Vigna unguiculata $\mathrm{cv}$. Blackeye & L/M,Mo & L/Mo & $\mathrm{L} /-$ & $\mathrm{L} /-$ \\
\hline Vigna unguiculata cv. Early Ramshorn Blackeye & $\mathrm{L} / \mathrm{M}, \mathrm{Mo}$ & L/Mo & $\mathrm{L} /-$ & $\mathrm{L} /-$ \\
\hline Vigna unguiculata $\mathrm{cv}$. Chinese Red & $\mathrm{L} / \mathrm{M}, \mathrm{Mo}$ & $\mathrm{L} / \mathrm{Mo}$ & $\mathrm{L} /-$ & $\mathrm{L} /-$ \\
\hline Nicotiana glutinosa & $l$ & $l$ & $-/$ Mo & $\mathrm{L} / \mathrm{Mo}$ \\
\hline
\end{tabular}

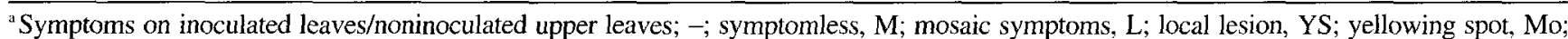
mottling symptoms, $l$; latent infection.

h.,c, Cowpea mosaic virus (CPMV), Soybean stunt virus (SstV) and Alfalfa mosaic virus (AMV) were reported by Hampton et al. (1978).

tion with SMV which is the most common cause of mosaic disease in vegetable soybean growing area.

Host range and symptomatology. The virus isolate $B-1$ maintained in Buffalo was used as virus source for biological characterization including host range and serological tests. For host range studies, nine indicator plants (Table 1) were used including Chenopodium amaranticolor, Gomphrena globosa, Cucumis sativus, Vigna unguiculata, Phaseolus vulgaris, and SMV-resistant soybean cultivars Marshall (PI54877), York (PI553038), Kwanggyo (PI4086710), and Buffalo (PI242131).

Soybean seeds were obtained from Dr. R.L. Nelson, USDA (Urbana, IL.); seeds of cowpea, Vigna unguiculata cv. Black-eye from M.F. Lofus, USDA (Belysville, MD); and seeds of bean, Phaseolus vulgaris cv. Top Crop and cv. Scotia (PI549751) from Molly Welsh. Indicator plants were inoculated mechanically at the seedling stage.

Serological test. Antiserurm against CPMV was obtained from Professor R. Gergerich, Department of Plant Pathology, University of Arkansas, USA, and antiserum against CMV was kindly provided by Dr. J. S. Kim, Horticultual Experiment Station, Suwon, Korea.

Antiserum against SMV was from ATCC (PVAS-94). Agar double diffusion tests for CPMV were done following the method of Purcifull and Bachelor (1977) using Buffalo leaves showing mosaic symptoms.

Virus purification and ultrastructural examination. Systemically infected Buffalo leaves were harvested 3 weeks after inoculation and purified using the Steere (1956) and Herbert (1963) methods. Buffalo leaves showing mosaic symptoms were prefixed in $1 \%$ Karnovksy's fixative solution. After post-fixation in $1 \%$ Osmium tetraoxide, dehydration was carried out in an ethanol series. Virus particles and inclusion bodies were observed by transmission electron microscope of infected leaf tissue, which were processed by the embedding method of Spurr (1969).

\section{Results and Discussion}

Host reaction. In the host range tests, Chenopodium amaranticolor inoculated with B-1 caused local lesions on the inoculated leaves and mosaic symptoms on the upper leaves (Table 1). Legume bean and cowpea $\mathrm{c}$ ultivars produced mosaic symptoms similar to CPMV but different from those of Soybean stunt virus, a legume strain of CMV (Hanada and Tochihara, 1982) and Alfalfa mosaic virus (Hampton et al., 1978; Table 1). Soybean differentials resistant to mosaic disease producing necrosis to virulent SMV strain G7 produced mosaic symptoms (Table 2).

Serological relation and morphology of the virus. The positive results in agar double diffusion tests (Fig. 2) strongly suggested that the isolate B-1 is an isolate of

Table 2. Reactions of soybean cultivars to B-1 isolate

\begin{tabular}{lcc}
\hline \hline Soybean cultivars & B-1 isolate & SMV-G5 $^{\mathrm{b}}$ \\
\hline Clark & $-/ \mathrm{Mo}^{\mathrm{a}}$ & $-/ \mathrm{M}$ \\
York (PI 553038) & $-/ \mathrm{Mo}^{\mathrm{a}}$ & $-/ \mathrm{M}$ \\
Marshall (PI 548693) & $-/ \mathrm{Mo}$ & $-/-$ \\
Ogden (PI 548477) & $-/ \mathrm{Mo}$ & $-/-$ \\
Kwang Kyo (PI 406710) & $-/ \mathrm{Mo}$ & N/N \\
Buffalo (PI 242131) & $-/ \mathrm{M}, \mathrm{Mo}$ & $-/-$ \\
\hline
\end{tabular}

"Reactions on inoculated leaves/noninoculated upper leaves; -; symptomless, $\mathrm{M}$; mosaic symptoms, $\mathrm{N}$; necrosis symptoms, Mo; mottling symptoms.

'SMV-G5 was used as control. 


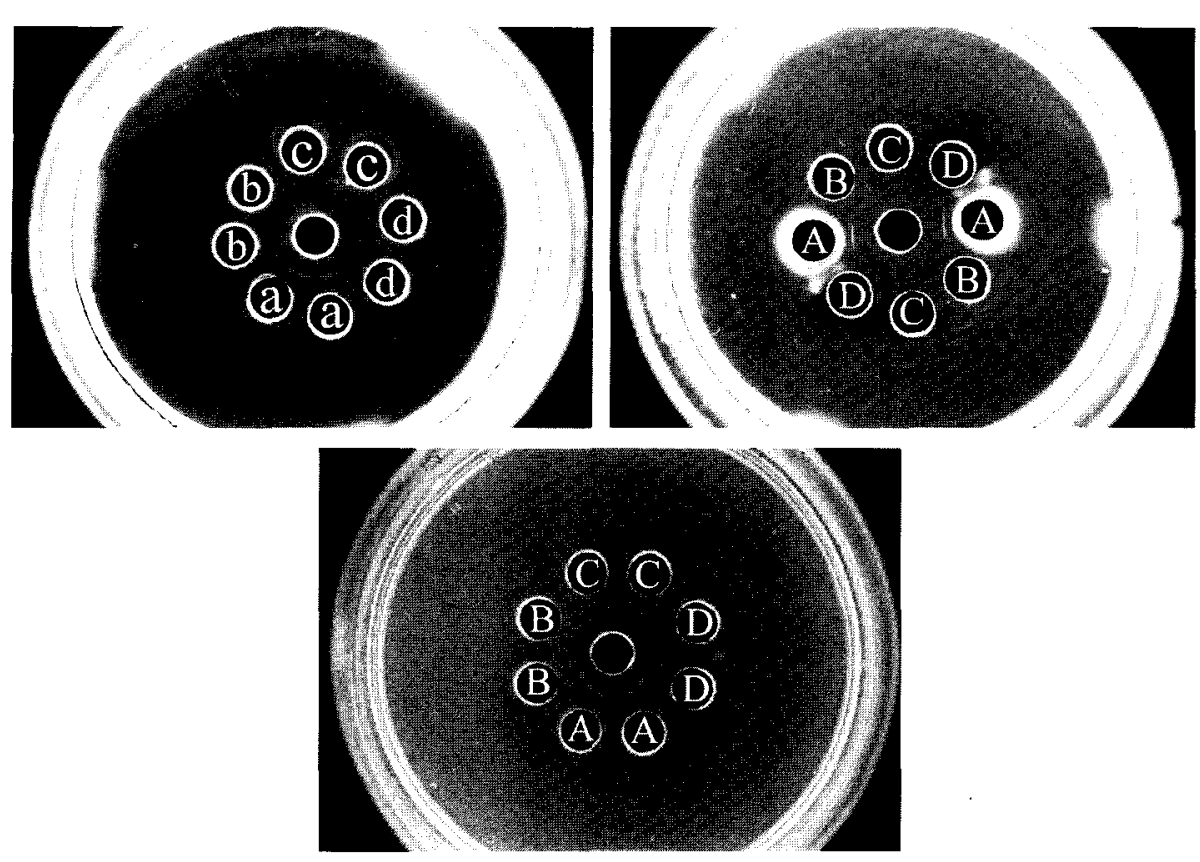

Fig. 2. Serological reaction in agar gel double diffusion test ( $0.7 \%$ agarose gel in $0.02 \mathrm{M}$ phosphate buffer, pH 7.0). Photograph; A: Soybean plant sap infected with SMV-G5, B: 3\% SDS (control), C: tobacco plant sap infected with CMV, D: soybean plant sap infected with B-1 isolate, central well contain SMV antiserum (ATCC, PVAS-94). Photograph; a: tobacco plant sap infected with CMV, b: soybean plant sap infected with SMV-G5, c: soybean plant sap infected with B-1 isolate, d: healthy tobacco plant sap (control), central well contain CMV antiserum. Photograph; A: soybean plant sap infected with B-1 isolate, B: tobacco plant sap infected with CMV, C: soybean plant sap infected with SMV-G5, D: healthy soybean plant sap (control), central well contain CPMV antiserum.

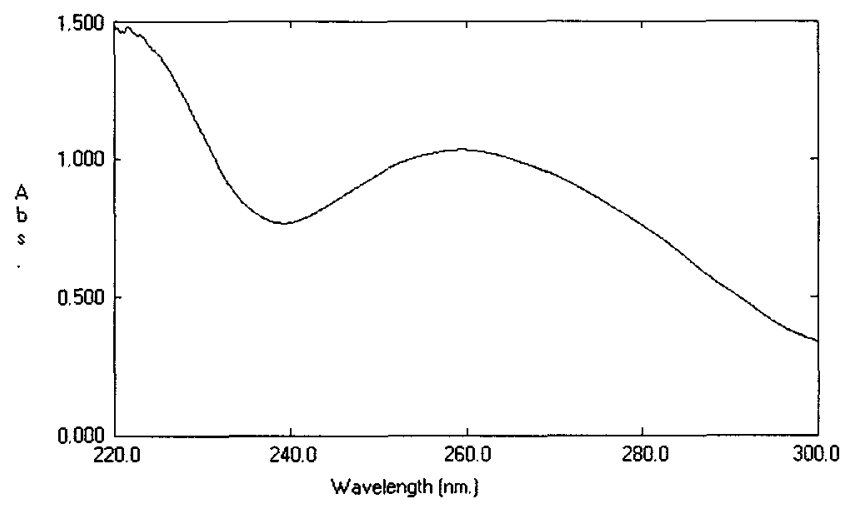

Fig. 3. Ultra-violet absorption spectra of purified virus from B-1 isolate.

CPMV. The B-1 virus particles were isometric about 24 $\mathrm{nm}$ in diameter and associated with membrane structures in the cytoplasm (Figs. 3 and 4; Van der Scheer and Groenewegen, 1971). In conclusion, results of this study suggest that the causal pathogen in the soybean was an isolate of CPMV based on serological and ultrastructural properties. This is the first report of CPMV from soybean in Korea.

Although beetles were reported as the vectors of CPMV, epidemiological aspects (Ross, 1968) of vegetable soybean mosaic disease caused by B-1 isolates, such as inoculum source, disease severity, and vector identification should be investigated to have a better knowledge of control measures for the virus.

\section{Acknowledgment}

This research was supported by the Andong National University research fund.

\section{References}

Cho, E. K. 1978. Virulence of soybean mosaic virus isolates obtained from soybean germplasm collection. M. S. thesis, University of Illinois, Urbana. 69p.

Hampton, R., Beczner, L., Hagedorn, D., Bos, L., Inouye, T., Barnett, O., Musil, M. and Meiners, J. 1978. Host reactions of mechanically transmissible legume viruses of the Northern temperate zone. Phytopathology 68:989-997.

Hanada, K. and Tochihara, H. 1982. Some properties of an isolate of the soybean stunt strain of cucumber mosaic virus. Phytopathology 72:761-764.

Hebert, T. T. 1963. Precipitation of plant viruses by polyethylene glycol. Phytopathology 53:362.

Purcifull, D. E. and Batchelor. 1977. Immunodiffusion tests with 

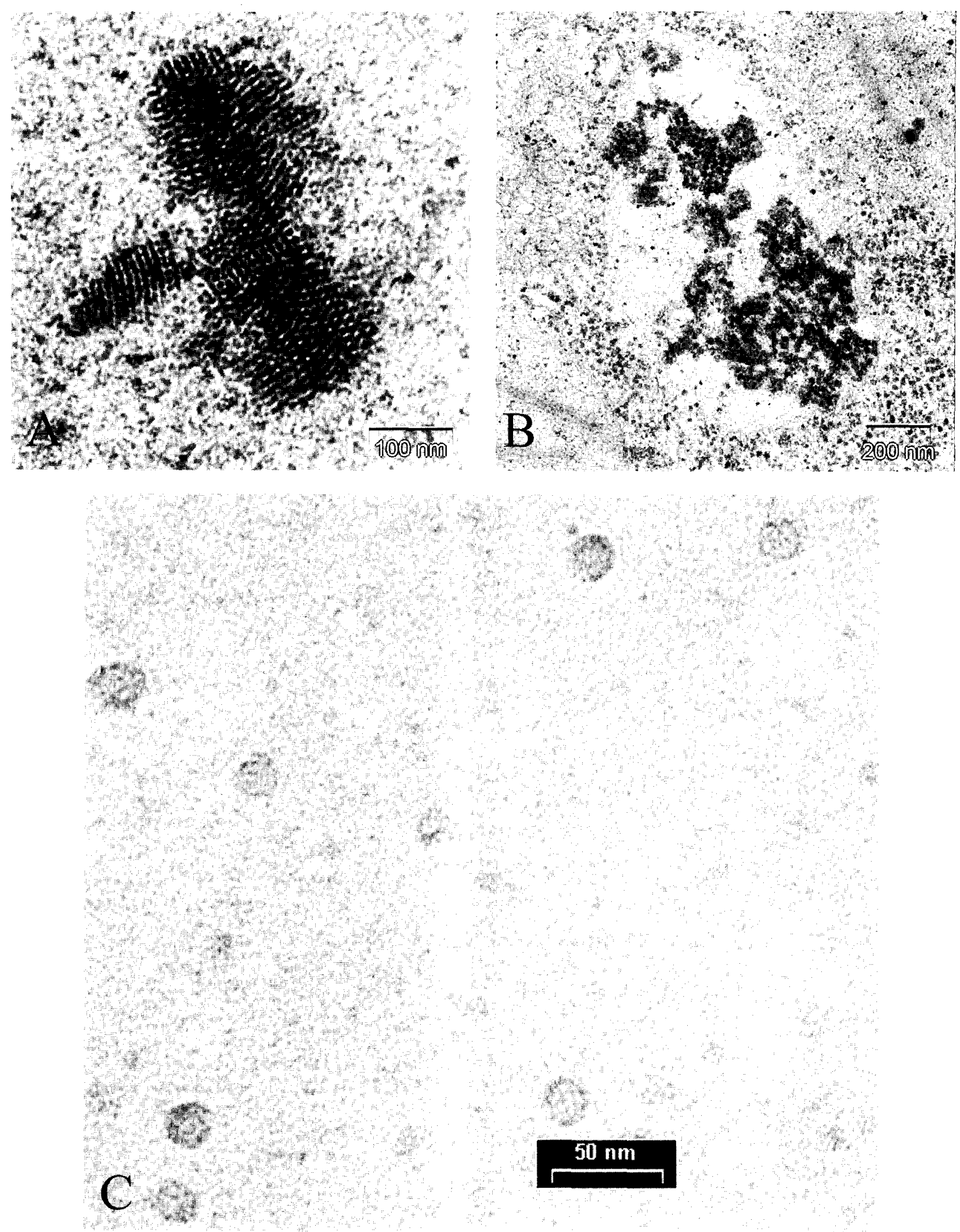

$50 \mathrm{~nm}$

Fig. 4. Accumulation of virus like particles in buffalo leaves $\mathbf{A}$ : particles in the cytoplasm $(\times 2500)$, B: membrane structures in the cytoplasm and particles in the vaculoe $(\times 8000)$, C: electron micrograph of purified virus from B-1 isolate $(\times 60000)$. Virus particles were negative stained with $2 \%$ uranyl acetate. 
sodium dodecyl sulfate (SDS)-treated plants viruses and plant viral inclusions. Flo. Agric. Exp. Stan. Tech. Bull. 788. 39p.

Ross, J. P. 1987. Viral and Bacterial Diseases: In: Wilcox, J-R (ed.), Soybeans' improvement, production and uses $\left(2^{\text {nd }} \mathrm{ed}\right)$. Agron. 888p.

Spurr, A. 1969. A low viscosity epoxy medium for electron microscopy. J. Ultrastruct. Res. 26:31-34.

Steere, R. L. 1956. Purification and properties of tobacco ringspot virus. Virology 25:487-494.

Takahashi, K., Tanaka, T., Iida, W. and Tsuda, Y. 1980. Studies on virus diseases and causal viruses of soybean in Japan. Bull. Tohoku Nat. Agric. Exp. Stn. 62:1-130.

Van der Scheer, C. and Groenenwegen, J. 1971. Structure in cells of Vigna unguiculta infected with cowpea mosaic virus. Virology 46:493-497. 